\title{
Giant hepatocellular carcinoma
}

\section{Gang Xu, Yilei Mao}

Department of Liver Surgery, Peking Union Medical College (PUMC) Hospital, PUMC and Chinese Academy of Medical Sciences, Beijing, China Correspondence to: Prof. Yilei Mao, MD, PhD. Department of Liver Surgery, Peking Union Medical College (PUMC) Hospital, PUMC and Chinese Academy of Medical Sciences, 1\# Shuai-Fu-Yuan, Wang-Fu-Jing, Beijing, China. Email: pumch-liver@hotmail.com.

Submitted Sep 24, 2020. Accepted for publication Oct 09, 2020.

doi: 10.21037/hbsn-20-727

View this article at: http://dx.doi.org/10.21037/hbsn-20-727
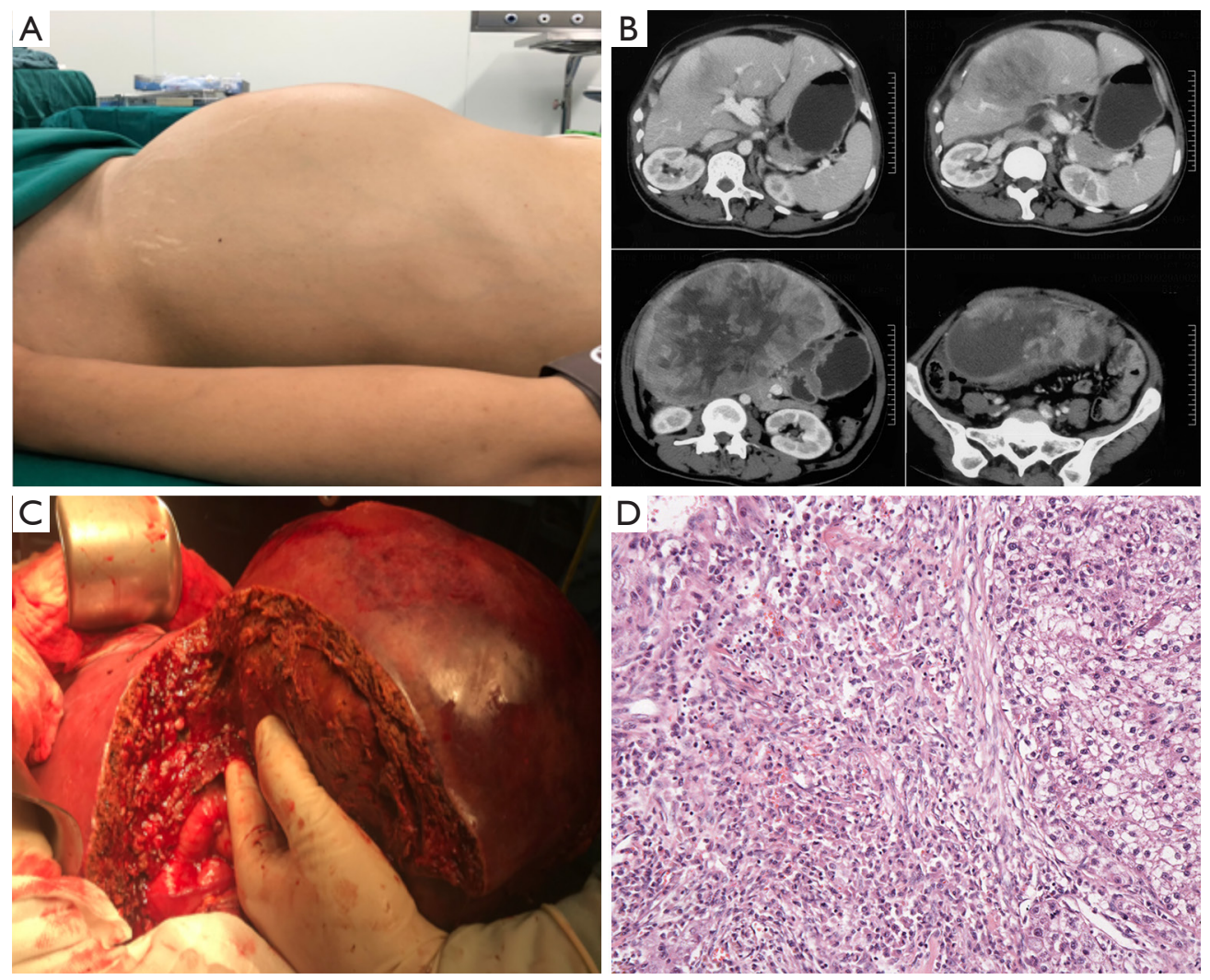

A 40-year-old female presented with progressive abdominal enlargement for 6 months (Panel A), along with severe abdominal distension and amenorrhea. She had not gone to hospital because she assumed herself to be pregnant, until the belly grew out of control. A giant lesion in abdomen was detected by computed tomography (Panel B). The patient was infected with hepatitis B virus, but the liver function and $\alpha$-fetoprotein were normal. Additionally, no distant metastasis was found preoperatively. The pre-operative diagnosis of the tumor origin was unclear. Exploratory laparotomy was performed and an exophytic tumor originating from the liver

was exposed. The patient underwent major hepatectomy (Panel C). Postoperative pathology is moderately differentiated hepatocellular carcinoma (hematoxylin and eosin stain, $\times 20$ ) (Panel D). Transarterial chemoembolization and sorafenib was administrated postoperatively. At a recent 3-month follow-up, no recurrence occurred.

\section{Acknowledgments}

The authors thank to Dr. Shunda Du for providing technical help to this research. 
Funding: This study was funded by CAMS Innovation Fund for Medical Sciences (CIFMS) (No. 2016-I2M1-001), Tsinghua University-Peking Union Medical College Hospital Cooperation Project (PTQH201904552) and Peking Union Medical College Graduate Student Innovation Fund (No. 2019-1002-45).

\section{Footnote}

Provenance and Peer Review: This article was commissioned by the editorial office, Hepatobiliary Surgery and Nutrition. The article did not undergo external peer review.

Conflicts of Interest: Both authors have completed the ICMJE uniform disclosure form (available at https://hbsn.amegroups. com/article/view/10.21037/hbsn-20-727/coif). YM serves as an unpaid editorial board member of Hepatobiliary Surgery and Nutrition. The other author has no conflicts of interest to

Cite this article as: $\mathrm{Xu}$ G, Mao Y. Giant hepatocellular carcinoma. HepatoBiliary Surg Nutr 2021;10(4):583-584. doi: $10.21037 /$ hbsn-20-727 declare.

Ethical Statement: The authors are accountable for all aspects of the work in ensuring that questions related to the accuracy or integrity of any part of the work are appropriately investigated and resolved. Written informed consent was obtained from the patient for publication of this manuscript and any accompanying images.

Open Access Statement: This is an Open Access article distributed in accordance with the Creative Commons Attribution-NonCommercial-NoDerivs 4.0 International License (CC BY-NC-ND 4.0), which permits the noncommercial replication and distribution of the article with the strict proviso that no changes or edits are made and the original work is properly cited (including links to both the formal publication through the relevant DOI and the license). See: https://creativecommons.org/licenses/by-nc$\mathrm{nd} / 4.0 \%$. 